\title{
RANOGOTICKÝ KRUCIFIX Z BUDMERÍC (OKRES PEZINOK)
}

\author{
MARTIN HANUŠ
}

\begin{abstract}
Abstrakt: Zriedkavé nálezy stredovekých krížov a krucifixov ponúkajú cenný pohlad do umeleckého a náboženského cítenia dobovej spoločnosti. Autor prezentuje nález malého medeného kríza s korpusom, ktorý sa našiel začiatkom 20. storočia bez presnejšej lokalizácie v extraviláne Budmeríc (okr. Pezinok). Príspevok v úvode prináša popis artefaktu, jeho štýlový rozbor a datovanie. Ďalej skúma pôvodnú funkciu krucifixu, ktorý bol odlomený, pravdepodobne, z liturgického predmetu a pokračuje otázkou jeho proveniencie. V poslednej stati sa autor pokúša lokalizovat'v rámci Budmeric a susedných obcí potenciálne miesto, kde artefakt mohol slúžit'svojej funkcii.
\end{abstract}

Kl'účové slová: krucifix - zlatníctvo - liturgia - cibórium - gotika-Budmerice.

\section{An early-Gothic crucifix from Budmerice (Pezinok district)}

\begin{abstract}
Rare finds of medieval crosses and crucifixes provide a valuable insight into the artistic and religious sentiments of the society in this period. The article presents the find of a small copper crucifix discovered in the early 20th century, without more precise locating, in the territory of the village of Budmerice (Pezinok district). The introductory part of the contribution describes the artefact and conveys its style analysis and dating. It further examines the original function of the crucifix which probably comes from a liturgical object, and addresses the issue of its provenance. In the last part the author attempts to locate a potential site where the artefact might have served its purpose in the area of Budmerice and the neighbouring villages.
\end{abstract}

Key words: crucifix - goldsmithery - liturgy-ciborium-Gothic-Budmerice.

\section{Úvod}

Autor príspevku bol oslovený so žiadost'ou o identifikovanie malého krížika majitel’om, vo vlastníctve ktorého rodiny sa nachádza po štyri generácie. Podla jeho svedectva bol nájdený na poli v Budmericiach, pričom miesto nálezu majitel' nevedel bližšie lokalizovat'. Podobne aj čas nálezu sa dal odhadnút' len rámcovo, niekedy na prelom 19. a 20. storočia, resp. začiatok 20. storočia.

\section{Opis nálezu ${ }^{1}$}

Predmet má tvar latinského kríža s plynulo sa rozširujúcimi koncami ramien (obr. 1). Jeho výška je $63 \mathrm{~mm}$ a dížka horizontálneho ramena $54 \mathrm{~mm}$. Śírka vertikálneho ramena sa nepravidelne v hornej a spodnej časti rozširuje zo 7,8/8,6 mm na 10,3/10,9 $\mathrm{mm}$. Podobne horizontálne rameno sa od stredu rozširuje nepravidelne zo 6,9/7,0 mm na 9,9/10,3 mm. Hrúbka kríža sa pohybuje v rozsahu 1,44 až 1,61 mm. Krížik má mierne nepravidelný tvar a os horizontálneho aj vertikálneho ramena nie je medzi opozitnými čast’ami totožná. Na spodnej strane je krížik ohnutý smerom dozadu a odlomený. Na hornom ramene, nad hlavou korpusu je viditel’ný tenký horizontálny tmavý pásik. Korpus je na krížiku fixovaný 3 okrúhlymi nitmi (Ø z prednej strany 1,8 mm, $\varnothing$ zo zadnej strany 2,6 mm). Jeho výška je $39 \mathrm{~mm}$ a šírka ramien $39,5 \mathrm{~mm}$. Hrúbka korpusu na trupe je 5,0 mm, na l'avom ramene 2,2 $\mathrm{mm}$. Hlava Krista je mierne naklonená dopredu a k pravému ramenu, pričom pohl'ad smeruje pred seba. Oči sú vel'ké mandl'ovité a zrejme zavreté. Dlhé vlasy sú zvlnené, splývajú cez uši po ramená a odhal'ujú vysoké hranaté čelo. Tvár nemá bradu ani fúzy, nos je plochý trojuholníkovitý. Ruky sú zl’ahka šikmo zdvihnuté, l’avá je takmer vystretá, pravá je v lakti mierne ohnutá. Dlane sú mierne zovreté a perforované nitom, pričom z prstov je vyformovaný len palec. Trup postavy je v náznaku esovite prehnutý a hladký, bez rytej

1 Lavá a pravá strana sú uvádzané z pohl'adu korpusu. 
výzdoby. Hrud’ má plasticky zvýraznené prsné svaly. Korpus je od pása až po kolená zakrytý dlhým rúškom (perisonium). To má v strede tri záhyby v tvare písmena $\mathrm{U}$ a na bokoch d’alšie vertikálne a diagonálne záhyby. Bohatšie zriasenie na pravom boku zrejme naznačuje miesto zviazania rúška, ktoré však nie je zobrazené. Nohy Krista sú fixované len jedným nitom bez podložky (suppedaneum) a úplne sa prekrývajú, takže vytvárajú jeden hladký zužujúci sa kužel'. Tesne pod rúškom sa nachádza tenký $(0,3 \mathrm{~mm})$ plasticky vystupujúci horizontálny strieborný pásik (potvrdené analýzou). Chodidlá sú protichodne orientované. Korpus je zo zadnej strany plochý. Celkovo možno vyobrazenie charakterizovat' ako Christus mortuus.

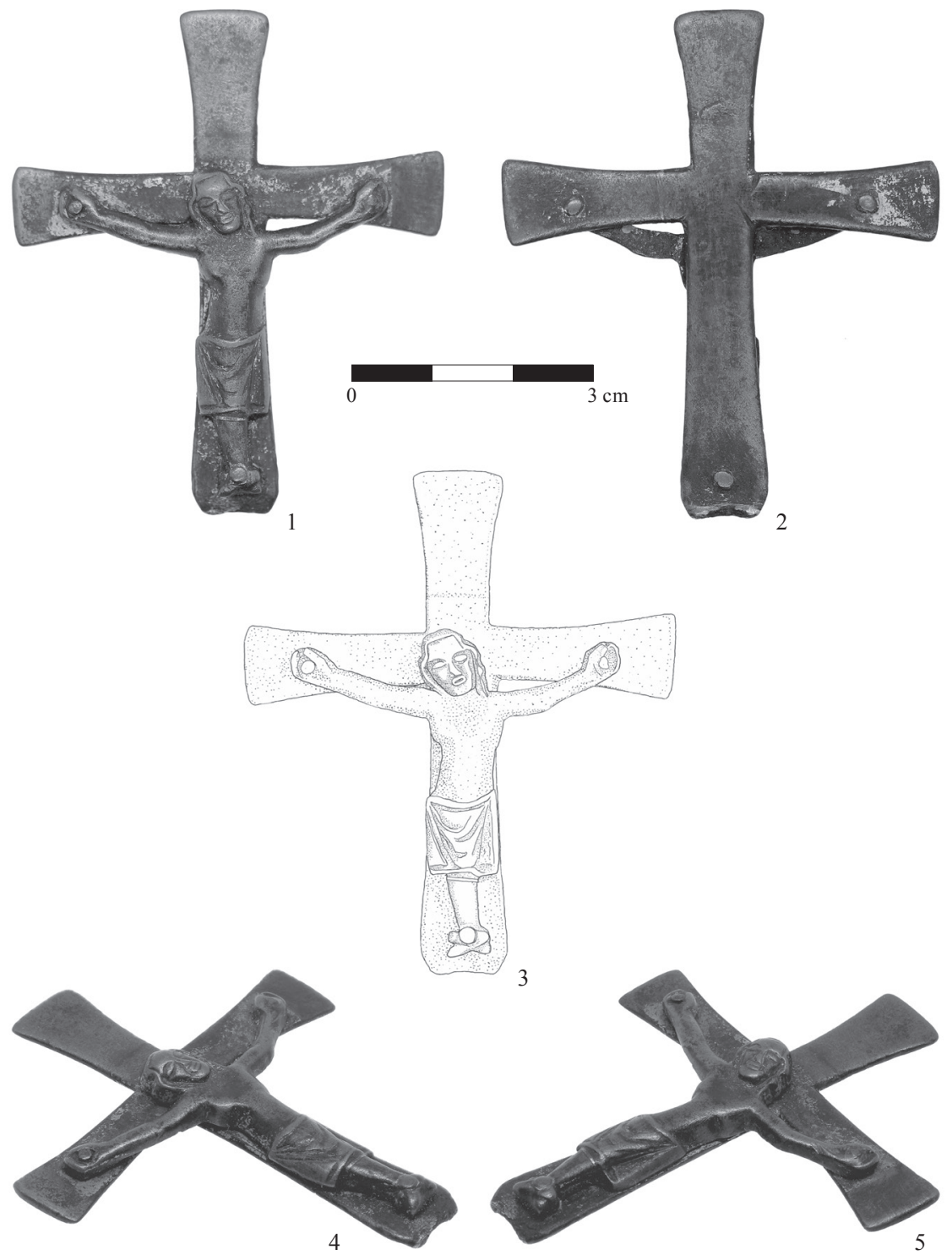

Obr. 1. Budmerice. Krucifix - čelný, zadný a bočný pohl'ad. Foto a grafika M. Hanuš.

Abb. 1. Budmerice. Kruzifix - Vorder-, Rück- und Seitenansicht. Foto und Grafik M. Hanuš. 
Celý krucifix váži 19,02 g. Kríž bol vystrihnutý z relatívne hrubého plechu (1,44-1,61mm), čo prezrádzajú zárezy v rohoch kríža z prednej a ešte výraznejšie zadnej strany. Korpus bol odliaty osobitne $\mathrm{v}$ jednostrannej forme. Následne obidve časti spojili pomocou nitov a pozlátili z oboch strán (potvrdené analýzou). Kríž aj korpus sú vyhotovené z medi, čo bolo identifikované spektrálnou povrchovou röntgenovou analýzou (tab. 1). ${ }^{2}$ Krucifix okrem toho na sebe nesie z prednej aj zadnej strany početné drobné zárezy a škrabance, ktoré môžu poukazovat' na deponovanie v zemi. Výraznejšie zárezy badat' na nose a l'avom predlaktí.

Tab. 1. Výsledok spektrálnej povrchovej röntgenovej analýzy kríža a korpusu.

Tab. 1. Ergebnis der spektralen Röntgenanalyse der Oberfläche von Kreuz und Korpus.

\begin{tabular}{|l|c|c|c|c|c|c|c|c|c|c|c|}
\hline Wt $\%$ & $\mathrm{Cu}$ & $\mathrm{Pb}$ & $\mathrm{Zn}$ & $\mathrm{Fe}$ & $\mathrm{Ni}$ & $\mathrm{Sb}$ & $\mathrm{Zr}$ & $\mathrm{Nb}$ & $\mathrm{Au}$ & $\mathrm{Ag}$ & $\mathrm{Sn}$ \\
\hline Kríž & $99,54 \%$ & $0,132 \%$ & $0,050 \%$ & $0,023 \%$ & $0,019 \%$ & $0,221 \%$ & $0,007 \%$ & $0,003 \%$ & - & - & - \\
\hline Korpus & $94,85 \%$ & $1,10 \%$ & $0,533 \%$ & $0,148 \%$ & $0,019 \%$ & - & - & - & $2,38 \%$ & $0,414 \%$ & $0,294 \%$ \\
\hline
\end{tabular}

\section{Krížz}

Tvar kríža s rozšíreným ukončením ramien má svoj pôvod už v starokrest’anskom a byzantskom umení (Lexikon der Kunst 1971, 726), pričom v strednej Európe ho od včasnostredovekého obdobia reprezentujú početné pektorálne a výnimočne aj procesiové kríže (Kouřil 2014; Roganský 2009). Medzi románskymi a gotickými oltárnymi, prípadne procesiovými krížmi majú túto formu typicky talianske (napr. obr. 2:6) a menej často švábske práce (Bloch 1992, 20; Müller 1994, 33). V rámci Uhorského král’ovstva sa vo všeobecnosti presadila latinská forma kríža (Kolba 2004, 19), pričom kríž s rozširujúcimi sa koncami nachádzame napr. už na hrobovej platni Ondreja I. (Uzsoki 1984). V blízkosti Budmeríc je tento typ vyobrazený napr. na hrobovej platni, resp. antependiu z kostola v Páci (Haviarová-Zvedelová 2011, obr. 8, 40-42). Kríž s rozširujúcimi sa koncami sa používa prakticky počas celých krest’anských dejín, aj ked' v istých variáciách, a sám o sebe nie je chronologicky citlivý. Najbližšiu analógiu, čo sa vel'kosti, tvaru a materiálu budmerického krížika týka, možno vidiet' na cibóriách z Cisnădioara (Rumunsko), Spišského Hrušova a súkromnej zbierky G. Kálmana (obr. 3:1-3; Éber 1907, ábr. 111; Kolba 1975, Abb. 1, 35), ktorým sa venujeme nižšie.

\section{Korpus}

Z hl'adiska datovania má výpovednú hodnotu predovšetkým samotný korpus. Hned' však treba konštatovat', že presnú paralelu s ním napriek preskúmaniu vel'kého počtu prameňov nepoznáme. Podarilo sa nám ale identifikovat’ podobnosti na úrovni jednotlivých čŕt vyskytujúcich sa na plastikách rôznych liturgických predmetov, oltárnych či procesiových krížov, ale aj knižných a nástenných mal'bách, prípadne vel'kých drevených formátoch. Uvádzané paralely tak pochádzajú z funkčne rôznych, obvykle väčších predmetov, prípadne sú výtvormi iného druhu umenia, čo treba pri hodnotení korpusu zobrat' do úvahy. Pri komparácii treba brat' taktiež na vedomie malé rozmery budmerického korpusu (39 mm), ktoré mohli viest' tvorcu k zjednodušeniu a skratke. Napriek tomu krucifix predstavuje štýlovo vyprofilovaný a čitatel'ný artefakt.

Skúmaný korpus má hlavu naklonenú mierne nabok a pohl’ad nasmerovaný pred seba, čo evidujeme najmä na plastikách datovaných od prvej štvrtiny 13. storočia do poslednej tretiny 14. storočia (obr. 2:1-3), kedy už pohlad Ukrižovaného obvykle smeruje do zeme (Kovács 1968, č. 14;

2 Prístroj: XRF analyzator NITON XL3t (výrobca: Thermo Fisher Scientific Niton, USA). 
Lovag 1999, č. 38, 62, 88, 89; Slivka 1999, 31, 32: Dvorníky). K účesu, ktorý nie je upravený na cestičku a splýva $\mathrm{v}$ jednej, resp. dvoch vlnách cez uši na ramená, nepoznáme blízku analógiu. V domácom materiáli má k nemu najbližšie účes na korpuse relikviárového kríža zo Spišskej Novej Vsi z druhej štvrtiny 14. storočia, štýlovo predstavujúci konglomerát talianskych a francúzskych vplyvov (Kolba 1987, 372; Wetter 2003, 805, č. 7.1; 2011, 260). Taktiež špecifické vysoké a široké čelo budmerického exemplára, vyplývajúce z jeho účesu, nachádzame napr. na niektorých horno-porýnskych relikviárových krížoch z poslednej tretiny 13. a začiatku 14. storočia (Fritz 1982, Abb. 62, 63, 198, 200) a najmä na toskánskych plastikách 14. až začiatku 15. storočia (obr. 2:7; Szmodis-Eszláry 1977). Celkovo podobnú formu tváre bez brady s vel'kými mandl’ovými očami a trojuholníkovitým nosom registrujeme na uhorskom korpuse datovanom rámcovo do 14. storočia (obr. 2:1; Lovag 1999, inv. č. 89). Budmerický korpus nemá na hlave korunu, použitú asi na tretine románskych krucifixov, ale ani tŕňovú korunu, charakteristickú pre gotické vyobrazenia Ukrižovaného, kde sa uplatňuje už od začiatku 13. storočia. Tŕňová koruna pritom typicky absentuje u talianskych a juho-švábskych krucifixoch (Bloch 1992, 14, 15, 36, 37; Müller 1994, 12, 24).

Na rozdiel od zväčša priamych románskych korpusov má budmerický krucifix jemne esovite prehnuté telo. Táto črta sa objavuje v byzantskej mal'be od 11. storočia (Onasch 1981, 226) a v západných bronzových plastikách od začiatku 12. storočia, avšak ešte s osobitne pribitými nohami (Bloch 1992, 36). Pri gotických trojklincových korpusoch sa pritom už v priebehu druhej polovice 13. storočia presadzuje odlišná výraznejšia esovitá profilácia, súvisiaca so silne skrčenými nohami, ktorá sa stáva dominantnou najmä v prvej polovici 14. storočia (napr. 3:7-8; Müller 1994, 27-29). V uhorskom materiáli máme esovitú profiláciu tela najskôr dochovanú až na spomínanom kríži zo Spišskej Novej Vsi z druhej štvrtiny 14. storočia (Wetter 2011, 260). $\mathrm{K}$ plasticky sa rozširujúcej hrudi budmerického korpusu nepoznáme v početnom európskom materiáli presnú analógiu. Čiastočnú paralelu s ním vidíme, na krucifixe z cibória zo sedmohradskej Cisnădioara (obr. 3:2a), kde na podobne jednoducho vytvarovaný valcovitý driek nadväzuje plasticky vyformovaný hrudník (Kolba 1975, 35, Abb. 35).

Prekrížené nohy fixované jedným klincom sa objavujú vo vel'kej plastike už v druhej polovici 12. storočia, ale širšie sa táto forma presadzuje od 20-tych rokov 13. storočia (Bloch 1992, 43) a všeobecne až od jeho polovice (Grove Encyklopedia 2012, 228; Müller 1994, 13, 14). Ich najstaršie príklady medzi domácimi kovovými plastikami nachádzame z druhej polovice až konca 13. storočia (obr. 2:4; Dvorníky: Slivka 1999, 31; a dva vzájomne príbuzné exempláre z Ete: Vízi-Miklós 1999, 237 a Rimavskej Soboty(?): Lovag 1999, č. 83). Dôležitou a starou črtou u gotických krucifixov sú vystreté nohy, ešte bez náznaku skrčenia, ktoré sa presadzuje až od polovice 13. storočia a dominuje až do polovice nasledujúceho storočia (napr. obr. 3:7-8; Müller 1994, 15, 23, 24, 27-29). Zaujímavým detailom budmerického krucifixu je, že dolné končatiny sa akoby zlievajú do jednej nohy, čo môže vyplývat' aj z jeho malých rozmerov. Pravdepodobnou predlohou tejto formy sú vyobrazenia Ukrižovaného s tesno priloženými, resp. niekedy až s neprirodzene prepletenými nohami, ktorým pri frontálnom pohlade dominuje len jedna noha. V domácom prostredí takto pôsobí napr. drevený ranogotický krucifix z Lendaku datovaný medzi roky 1260-1280 (Suckale 2003, 690, 691), či freska na neskororománskom tympanóne z Hrabušíc (obr. 2:10; Togner-Plekanec 2012, 187, 189) datovaná pred polovicu 14. storočia. V západnej Európe ich nachádzame napr. na francúzskych, resp. franko-flámskych knižných miniatúrach z 13. a začiatku 14. storočia (napr. obr. 2:8-9; Getty 1270; 1300). Sprievodnou črtou týchto vyobrazení sú niekedy protichodne smerujúce chodidlá. Na budmerickom krucifixe vidíme chodidlá v extrémnej pozícii orientované proti sebe (obr. 1), k čomu v drobnej plastike nepoznáme analógiu.

Hornú čast' nôh budmerického krucifixu zakrýva dlhé bedrové rúško siahajúce po kolená, pravdepodobne zviazané na pravom boku (obr. 1). Dlhé rúško v západnom umení dominovalo od karolínskeho obdobia, pričom spôsob jeho vyobrazenia hrá dôležitú úlohu v typológii románskych (Bloch 1992), ale aj gotických krucifixov (Müller 1994). Na prelome 14. a 15. storočia sa už stabilne uplatňuje krátke rúško (Müller 1994, 17), v toskánskej plastike ale siaha po kolená ešte aj 
v prvej polovici 15. storočia (Szmodis-Eszláry 1977, 82). V uhorskom materiáli od konca 14. storočia rúško už obvykle zasahuje do polovice stehien (Cónová 1999; Kolba 1980; 2004, inv. č. 103, 105, 106, 108-111; Lovag 1999, inv. č. 63; Toranová 1983, inv. č. 2-7). Najbližšiu paralelu s bedrovým rúškom budmerického exempláru nachádzame na korpuse z vatikánskeho Museo Sacro zo začiatku 13. storočia (obr. 2:5; Müller 1994, 45, Abb. 2). Tento korpus pritom vykazuje viacero podobných čŕt aj v celkovom prevedení postavy. Použitie záhybov v tvare písmena U v domácom materiáli prvý raz registrujeme na drevenom krucifixe z Lendaku (1260-1280). Celkové riešenie rúška tu však predstavuje odlišný typ (Suckale 2003, 690, 691). V kovovej plastike sa záhyby, i ked' výrazne plytšie, prvý raz objavujú na liatom korpuse procesiového kríža z Visegrádu (obr. 2:3), datovanom do druhej tretiny, resp. k polovici 14. storočia (Bodor 1983, obr. 1; Lovag 1994, 303, V-18; Marosi 1983, č. 183, 325). Tento korpus sa pritom vyznačuje d’alšími zaujímavými paralelami s budmerickým exemplárom: nohy sú málo vypracované a čiastočne sa zlievajú, hlava je naklonená napravo s pohl'adom upretým dopredu, rovnako chýba brada a podobný je aj celkový výraz tváre. Líši sa však už výrazne prehnutými rukami. Takmer identický korpus sa našiel aj v Balatongyöröku (Bodor 1983, obr. 2).

Dôležitým detailom pre datovanie budmerického krucifixu je poloha rúk. Ruky siahajú do výšky tváre a vytvárajú len mierny oblúk, pričom dlane smerujú šikmo do strán. Táto forma je charakteristická pre prvú polovicu, resp. druhú tretinu 13. storočia, ale nachádzame ju aj na plastikách v druhej polovici storočia (obr. 2:5-6). Vtedy sa však už presadzujú ruky vytvárajúce silný oblúk, v dôsledku čoho korpus visí nižšie na kríži (napr. obr. 2:8-9; Müller 1994, 14, 25, Abb. 1, 5, 7, 19, 53, 55, 70). Progresívnou črtou na budmerickom korpuse sú mierne zovreté dlane. Nenachádzame ich takmer na žiadnom románskom krucifixe (ojedinelá výnimka: Bloch 1992, VI A4), naopak ide o črtu gotických korpusov dominantnú až v 15. storočí (Kolba 1980; 2004, inv. č. 105, 106, 109-111; Müller 1994, 26, Abb. 67, 84, 94, 124, 149).

Celkovo možno konštatovat', že budmerický krucifix reprezentuje štýl prechodnej fázy medzi frontálne zobrazeným vít’azným živým Vykupitel’om s otvorenými očami románskych krucifixov (Christus triumphans), ktoré dominuje v domácom uhorskom materiáli do konca 13. storočia (Lovag 1979, 13, 14; 1999, 12,13) a gotickým umením, ktoré zobrazuje trpiaceho Krista (Christus patiens) s naturalisticky kolabujúcim telom visiacim na kríži (The Grove Encyklopedia 2012, 227-231; Kolba 2004, 20; Kovács 1968, 17). Skúmaný korpus ešte nevyjadruje smrtel’ný zápas plne vyvinutých gotických krucifixov, jeho tvár má „spiaci“ výraz, postava je vzpriamená, len s mierne naznačeným esovitým prehnutím, nohy sú takmer vystreté a rovnako ruky sú len mierne ohnuté, takže telo na kríži viac stojí než visí. Korpus charakterizujeme ako ranogotický a na základe rozboru uvedených paralel a diagnosticky citlivých čŕt ho možno datovat' do druhej až tretej tretiny 13. storočia.

\section{Funkcia krucifixu}

Vzhl'adom na malé rozmery a formu krížika (výška $63 \mathrm{~mm}$ ) možno vylúčit' jeho použitie ako oltárneho, procesiového či relikviárového kríža, alebo pacifikálu. ${ }^{3}$ Rovnako chýbajúca úchytka prezrádza, že možno vyradit' jeho funkciu ako pektorálneho kríža. Krucifix vel’mi pravdepodobne pochádza z vrcholu liturgického predmetu, z ktorého bol odlomený, na čo poukazujú stopy na jeho spodnej časti. Obojstranné pozlátenie kríža taktiež prezrádza, že išlo o prenosný predmet, ktorý mohol byt' viditel'ný z rôznych strán.

Malé kríže, prípadne krucifixy sa často uplatňovali na vrcholoch monštrancií (Braun 1932, 402). Kult Božieho Tela, na účel ktorého vznikli, ustanovil Urban IV. v roku 1264, ale jeho slávenie v rámci celej Cirkvi sa rozšírilo len postupne. V Čechách sa slávil až od roku 1319, pričom $\mathrm{k}$ jeho širšiemu prijatiu $\mathrm{v}$ mestskom prostredí dochádza v polovici 14. storočia a univerzálnemu

3 Tie bývajú vysoké minimálne $15 \mathrm{~cm}$, pri románskych duálnych krížoch obvykle $20-30 \mathrm{~cm}$, pri gotických oltárnych križoch $30-40$ cm (Braun 1932, 466-492; 1940, 458-492; Cónová 1999; Lovag 1999). 

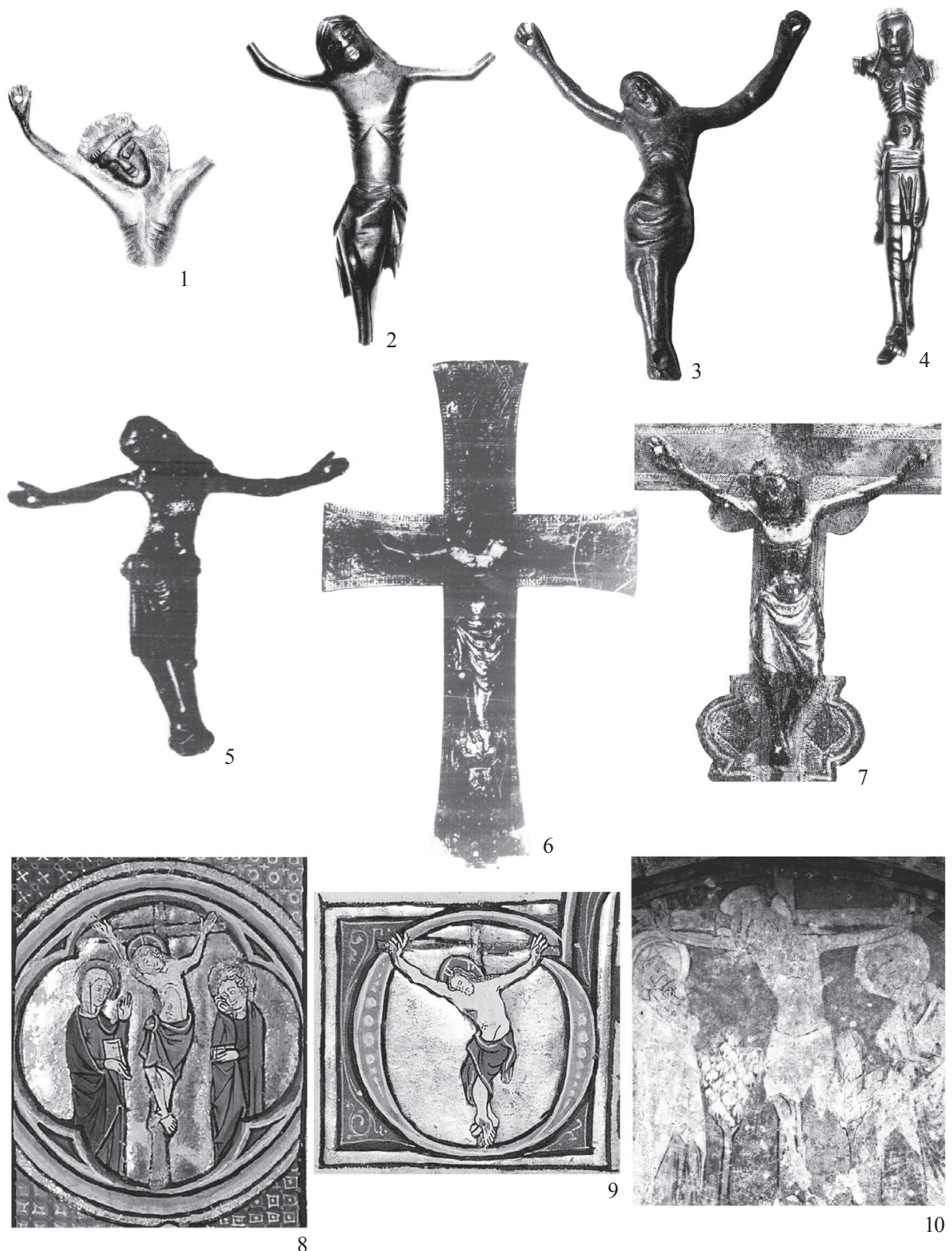

6

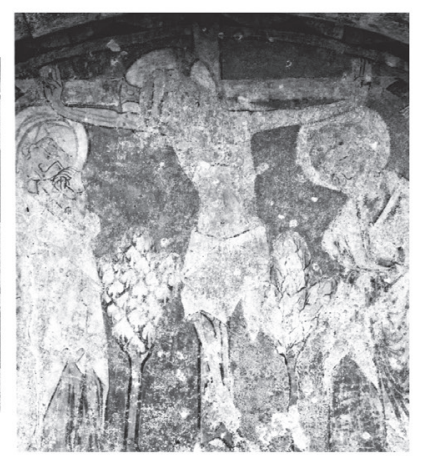

10

Obr. 2. Paralely k budmerickému krucifixu. 1 - Uhorsko, 14. storočie; 2 - Uhorsko, 14. storočie; 3 - Visegrád, farský kostol, polovica 14. storočia; 4 - Uhorsko, koniec 13. storočia; 5 - Taliansko(?), začiatok 13. storočia; 6 - Toskánsko, posledná tretina 13. storočia; 7 - Toskánsko, 14. storočie; 8 - Franko-flámska miniatúra, okolo 1270; 9 - Franko-flámska miniatúra, okolo 1300; 10 - Hrabušice, prvá polovica 14. storočia. Podl’a Lovag 1999, Abb. 83, 88, 89 (1, 2, 4); Lovag 1994, Abb. V-18 (3); Müller 1994, Abb. 2 (5); Müller 1994, Abb. 127 (6); Szmodis-Eszláry 1977, obr. 52 (7); Getty 1270 (8); Getty 1300 (9); Togner-Plekanec 2012, 189 (10). Rôzne mierky.

Abb. 2. Parallelen zum Kruzifix aus Budmerice. 1 - Ungarn, 14. Jahrhundert; 2 - Ungarn, 14. Jahrhundert; 3 - Visegrád, Pfarrkirche, Mitte 14. Jahrhundert; 4 - Ungarn, Ende 13. Jahrhundert; 5 - Italien (?), Anfang 13. Jahrhundert; 6 - Toskana, letztes Drittel 13. Jahrhundert; 7 - Toskana, 14. Jahrhundert; 8 - Franko-flämische Miniatur, um 1270; 9 - Franko-flämische Miniatur, um 1300; 10 - Hrabušice, erste Hälfte 14. Jahrhundert. Nach Lovag 1999, Abb. 83, 88, 89 (1, 2, 4); Lovag 1994, Abb. V-18 (3); Müller 1994, Abb. 2 (5); Müller 1994, Abb. 127 (6); Szmodis-Eszláry 1977, Abb. 52 (7); Getty 1270 (8); Getty 1300 (9); Togner-Plekanec 2012, 189 (10). Verschiedene Maßstäbe. 
rozšíreniu až v poslednej štvrtine 14. storočia (Mudra 2017, 12). Tomuto zodpovedá aj fakt, že v inventároch európskych kostolov sú monštrancie väčšinou doložené až od druhej polovice 14. storočia (Braun 1932, 353-357; Fritz 1982, 33) a ani v uhorskom materiáli staršie nepoznáme. Vzhl'adom na uvedené považujeme pôvod budmerického krucifixu z monštrancie $\mathrm{v}$ danom časovom horizonte a $\mathrm{v}$ dedinskom prostredí za málo pravdepodobný. V prospech toho hovorí aj pozorovanie, že v bohatej pramennej báze zo strednej Európy, kde monštrancie predstavujú po kalichoch druhý najčastejšie doložený liturgický predmet (Cónová 1999, 3; Fritz 1982, 31; Kolba 2004, 6), je známy len jeden exemplár s krížom tohto tvaru, i to až zo 16. storočia (Divald 1907, 34, obr. 32).

Ďalšou alternatívou je, že by kríž mohol pochádzat' z vrcholu rôznych druhov relikviárových schránok. Napriek preskúmaniu rozsiahleho európskeho materiálu sme nenašli relevantnú analógiu s budmerickým krucifixom. Len čiastočne príbuzná forma kríža bez korpusu sa ojedinele vyskytla na ostensóriu z Florencie z 15. storočia (Braun 1940, 331, 334, Abb. 364). Výskyt relikviára $\mathrm{v}$ dedinskom prostredí je taktiež menej pravdepodobný.

Malými krížmi a krucifixmi mohli byt' ozdobené rozličné druhy liturgických predmetov, ako napr. kadidelnice (napr. Lovag 1999, č. 202) či kovové veká krstitel'níc (napr. Tari 2018; Toranová 1991, inv. č. 142-144; Wick 1936, 254). V prípade kadidelníc však ide o proporčne menšie, a pri krstitel'niciach zase väčšie exempláre. V tejto kategórii liturgických predmetov chronologicky, ani formálne relevantné paralely so skúmaným artefaktom rovnako nie sú známe.

\section{Cibórium}

Z početného uhorského aj európskeho materiálu zlatníckych prác sme paralelu, čo sa formy a rozmerov krížika týka, identifikovali len na troch cibóriách pochádzajúcich z niekdajšieho Uhorska. V prvom prípade ide o známe cibórium zo Spišského Hrušova (obr. 3:1), uložené v Mad’arskom národnom múzeu, ktoré predstavuje najstarší príklad tohto liturgického náčinia zo Slovenska. Vyhotovené je z pozlátenej medi a tvorí ho hexagonálna pyxida s ihlanovitým vekom stojaca na oválnej nôžke so štyrmi hrotitými výbežkami, so šest'bokým driekom a nodusom. Jeho celková výška je $39 \mathrm{~cm}$. Bočné steny pyxidy sú zdobené gravírovaným christologickým cyklom a veko s postavami sv. Petra a Pavla a štyroch evanjelistov. Na vrchole cibória sa nachádza analogický krížik s rozširujúcimi sa ramenami z pozláteného strieborného plechu so strieborným korpusom. Predpokladá sa, že cibórium vzniklo okolo roku 1360 v spišskej zlatníckej dielni na král’ovskú, resp. biskupskú objednávku pre kostol v Spišskom Hrušove založenom L’udovítom I. Cibórium má výtvarne heterogénny charakter a reprezentuje kombináciu talianskeho a stredoeurópskeho lineárneho štýlu (Kolba 1975, 288-304; 1983a, č. 165, 310, 311; 2004, č. 89 tam staršia literatúra; Marosi 1985, 44; Ruttkay 1979, 99; Šourek 1938, obr. 531; Toranová 1983, č. 46). Kríž na cibóriu však pravdepodobne nie je pôvodný a súvisí s jeho mladšou opravou v 16.-17. storočí, čo prezrádza jeho odlišný materiál, forma korpusu, ako aj nápisová páska (Kolba 1975, 289; Šedivý 2018, 281). Krucifix by však mohol predstavovat' kópiu pôvodného kríža. ${ }^{4}$

Druhú a klúčovú analógiu s budmerickým krucifixom nachádzame na cibóriu z Kostola sv. Michala v Cisnădioara (mad'. Kisdisznód, nem. Michelsberg), v Sedmohradsku (obr. 3:2). Toto cibórium formálne aj proporčne predstavuje zároveň najbližšiu paralelu s cibóriom zo Spišského Hrušova, jeho celkové vyhotovenie je však skromnejšie. Výzdobu tvorí len nápisová páska na oktogonálnej schránke, $v$ rámci ktorej je použitý aj vegetabilný ornament podobný ako na hrušovskom exemplári. Rozdiel voči nemu vykazuje najmä čo sa týka okrúhleho podstavca a drieku s jednoduchším nodusom. Ten však bol na hrušovskom cibóriu (obr. 3:1) do vel'kej miery v mladšom období reštaurovaný a upravovaný, takže jeho pôvodnú podobu pravdepodobne nepoznáme. J. Kolba $(1975,323)$ usudzuje, že cibórium z Cisnădioara reprezentuje dielo uhorskej

4 Takáto situácia sa predpokladá napr. na Besánskom cibóriu, kde bol pri analogickej oprave vrcholového kríža opätovne použitý autentický korpus, pričom kríž vyhotovili nanovo, pravdepodobne však napodobňujúc typickú stredovekú formu pôvodného križa (Kolba 1975, 306; 2004, inv. č. 90). 
dielne 14. storočia, pričom jeho nemecký nápis „HILF GOT MARIA BAROT HILF“55 (Roth 1908, 86), prezrádza, že jeho autor alebo objednávatel' mal nemecký pôvod. Zlatnícke remeslo v Sedmohradsku pritom malo byt' do polovice 15. storočia výlučne v rukách Sasov (Bielz 1957, 9). Nápis je vyhotovený vo vrcholnogotickej majuskule, takže datovanie cibória možno spresnit' na druhú tretinu 14. storočia. Od 1370/1380 toto písmo pomerne rýchlo začala vytláčat' gotická nápisová minuskula (konzultácia J. Šedivý). Sedmohradské cibórium tak možno zaradit' do rovnakého obdobia ako hrušovský exemplár.

Korpus na cibóriu z Cisnădioary je oproti budmerickému exempláru pravdepodobne mladší. Naznačuje to kratšie rúško a šikmo nahor smerujúce ruky (obr. 3:2a), čo sú črty objavujúce sa najskôr od polovice 14. storočia (Müller 1994, 17, 25). Vo vzt’ahu k budmerickému krucifixu má však podobne jednoducho vyformovaný trup. Detaily Ukrižovaného, žial', môžeme sledovat' len v nižšej kvalite, pretože cibórium sa po druhej svetovej vojne zrejme stratilo a dostupné je len pôvodné vyobrazenie publikované V. Rothom (1922; prevzaté Kolba 1975, Abb. 35). Korpus však pôsobí akoby primárne nebol navrhnutý pre kríž ukončujúci cibórium, čo prezrádzajú najmä jeho krátke neúplné nohy (obr. 3:2a). To zodpovedá pozorovaniu, že kríže a korpusy sa niekedy vyrábali nezávisle a zmontovali sa až na objednávku a podl’a vkusu objednávatela (Müller 1994, 19, 20). Odlomená pravá ruka Krista a odkryté priečne rameno kríža taktiež odhal’ujú, že nebol na kríž fixovaný pomocou nitu, ale bol pripevnený iným spôsobom. V akom čase bol korpus aplikovaný na cibórium z Cisnădioara a či je dielom pôvodného zlatníka, už z dostupných prameňov nemožno posúdit'.

Tretia analógia s budmerickým krucifixom pochádza zo súkromnej zbierky G. Kálmána (obr. 3:3). Ide opätovne o formálne príbuzné polygonálne cibórium vyhotovené z pozlátenej medi, avšak už z 15. storočia, ktorého pôvodná proveniencia nie je známa. Cibórium stojí na viaclaločnej nohe s nodusom, schránka je zdobená rytou výzdobou zobrazujúcou tvár Krista na Veronikinej šatke a anjelov, pyramidálny uzáver dekorujú po stranách ornamentálne prvky a na jeho vrchole sa nachádza kríž s mierne sa rozširujúcimi koncami a korpusom. Ten už predstavuje mladší prepracovanejší typ s krátkym rúškom (Éber 1907, 61, ábr. 111).

Z Uhorska sú okrem toho známe d’alšie analogické polygonálne cibóriá, niektoré taktiež ukončené krížom, avšak odlišnej formy. Zo Sedmohradska pochádzajú d’alšie tri z kostolov v Brădeni, Cincul Mare a Seica Mare (Kolba 1975, 322-324, Abb. 36-38). Okrem toho sú známe d’alšie presne nelokalizované exempláre, a to už spomenuté cibórium z Bésánovej zbierky (dat. 1370) uložené v Nemzeti múzeu (Kolba 1975, 304-317; 2004, inv. č. 90, 66) a tri cibória z Múzea v Ostrihome (Cséfalvay 1984, ábr. 28; 1992, ábr. 35; Kolba 1975, 317-322, Abb. 32-34; 1987, 371, 372; Rúzsa 1986, ábr. 32).

J. Kolba $(1975,324)$ konštatuje, že tento typ cibórií vytvára pomerne jednotný obraz bez ohl'adu na to, či boli vyhotovené v hornom Uhorsku, resp. Slovensku, v okolí Budína alebo Sedmohradsku. Najväčšie variácie vykazujú vo výzdobe, ale konštrukčne a proporčne sú si vel'mi blízke. Výroba polygonálnych cibórií sa realizovala relatívne dlhý čas od začiatku 14. storočia až do raného 16. storočia, pričom paralely s nimi v istých variáciách pochádzajú z celej Európy (obr. 3:7, 8; Braun 1932, 309-314; Kolba 1975, 323-325, 328). Zaujímavé je, že zriedkavá forma kríža s rozširujúcimi sa koncami sa viac ráz objavuje aj na slovenských cibóriach zo 17. a 18. storočia (Toranová 1983, č. 56, 57, 67).

Cibória zo Spišského Hrušova, Cisnădioary a zbierky G. Kálmána predstavujú klúčové paralely s budmerickým nálezom. Vývoj týchto schránok na uchovávanie konsekrovaných hostií sa vinie od ranokrest’anských čias, pričom ho formovali postupne sa vyvíjajúce teologické idey. V písomných prameňoch sa toto kultové náčinie najčastejšie označovalo ako pyxis, a až od polovice 17. storočia ako cibórium (Braun 1932, 282-291). Do 13. storočia mali cibória obvykle formu menších nádob (Ø 5-8 cm; obr. 3:4; napr. Kovács 1968, 27, Abb. 33-36; Lovag 1999, č. 136).

5 Ide o klasický nápis Gott hilf-Maria berot (hornonemecké berot, v dnešnej nemčine berate - t. j. slovensky porad'). Tvar BAROT mohol vzniknút' nedopatrením vzhl’adom na rezervy v gramotnosti remeselníkov (Albu 2009, 113, pozn. 187; konzultácia prof. J. Šedivý). 

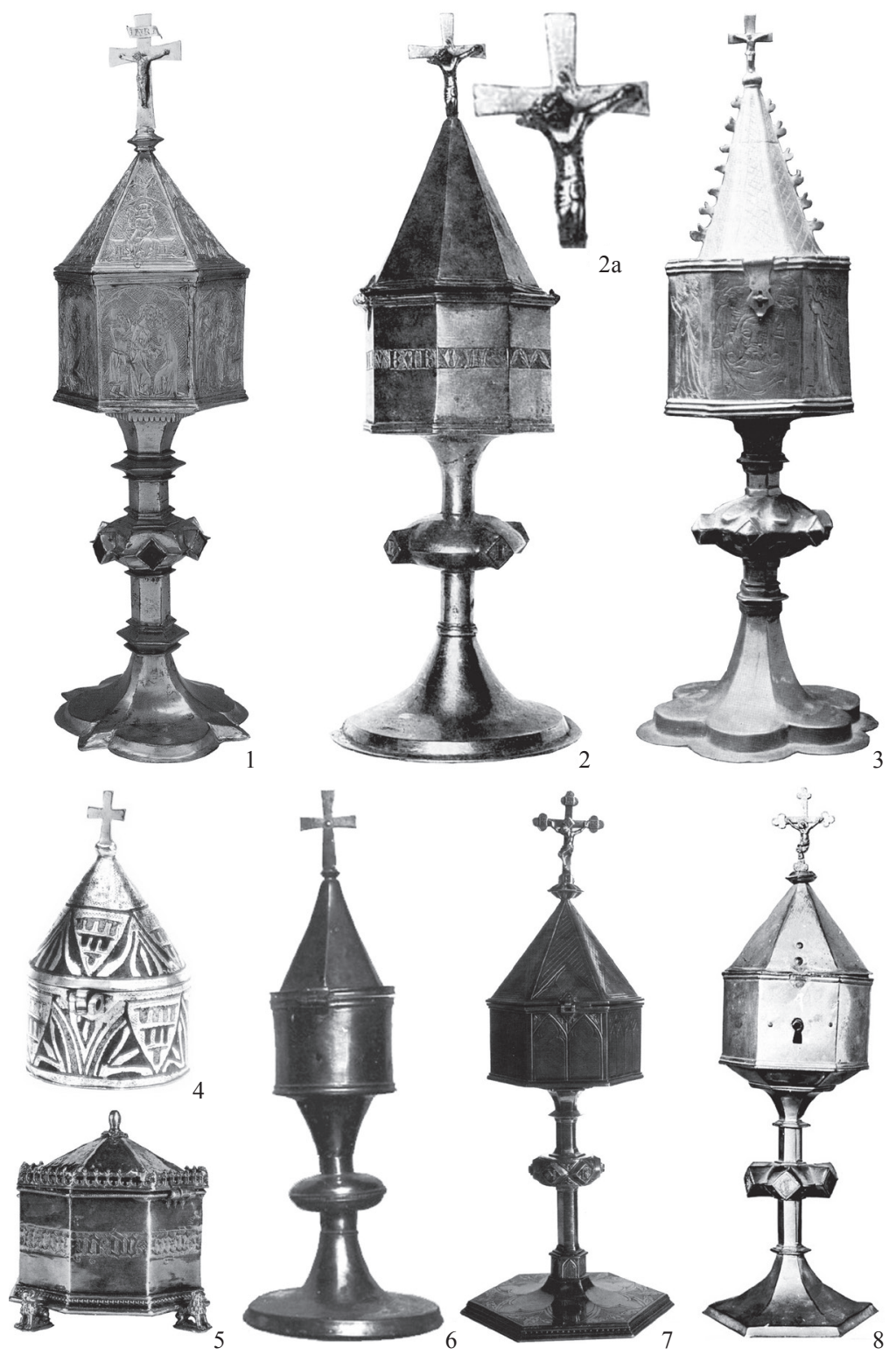

Obr. 3. Cibória. 1 - Spišský Hrušov, okolo 1360; 2 - Cisnădioara, 14. storočie; 3 - Zbierka G. Kálmana, Uhorsko(?), 15. storočie; 4 - Limoges, druhá polovica 13. storočia; 5 - Nemecko, 14. storočie; 6 - Nemecko(?), 13. storočie; 7 - Eltz, začiatok 14. storočia; 8 - Friedberg (Nemecko), okolo 1400. Podl'a Kolba 2004, Abb. 89 (1); Kolba 1975, Abb. 35 (2a, b); Éber 1907, ábr. 111 (3); Lovag 1999, Abb. 136 (4); Fritz 1982, Abb. 613 (5); Europeana, Bayerisches Nationalmuseum: obj05303931 (6); Fritz 1982, Abb. 97 (7); Europeana, Staatliche Kunstsammlungen \& Hessisches Landesmuseum, Kassel: obj32047496 (8). Rôzne mierky.

Abb. 3. Ziborien. 1 - Spišský Hrušov, um 1360; 2 - Cisnădioara, 14. Jahrhundert; 3 - Sammlung G. Kálman, Ungarn (?), 15. Jahrhundert; 4 - Limoges, zweite Hälfte 13. Jahrhundert; 5 - Deutschland, 14. Jahrhundert; 6 - Deutschland (?), 13. Jahrhundert; 7 - Eltz, Anfang 14. Jahrhundert; 8 - Friedberg (Deutschland), um 1400. Nach Kolba 2004, Abb. 89 (1); Kolba 1975, Abb. 35 (2a, b); Éber 1907, ábr. 111 (3); Lovag 1999, Abb. 136 (4); Fritz 1982, Abb. 613 (5); Europeana, Bayerisches Nationalmuseum: obj05303931 (6); Fritz 1982, Abb. 97 (7); Europeana, Staatliche Kunstsammlungen \& Hessisches Landesmuseum, Kassel: obj32047496 (8). Verschiedene Maßstäbe. 
V nasledujúcom období sa typickou formou stal nový druh cibória s nôžkou, pričom najstaršie príklady tohto druhu poznáme z 13. storočia. Vtedy mala schránka obvykle cylindrickú formu (obr. 3:6) a od začiatku 14. storočia sa presadzuje polygonálny tvar (obr. 3:7; Braun 1932, 280-347; Fritz 1982, 73, 74; Grove Encyklopedia 2012, 86-88; Kolba 1975, 284; 2004, 16, 17; Stehlíková 2003, 82, 83).

Čo sa týka materiálového zloženia na výrobu liturgických predmetov sa v Uhorsku od 14. storočia uplatňovala predovšetkým med'. Príčinou tejto preferencie bola l'ahšia cenová dostupnost', vzhl'adom na množstvo materiálu potrebného pre vyhotovenie väčších predmetov, ale aj lepšia ohybnost' pri práci za studena (Kolba 2004, 17, 18, 20; Lovag 1979, 51). Používanie rôznych materiálov bolo pri liturgických predmetoch limitované cirkevnými predpismi. Cibóriá, podobne ako kalichy, predstavujú vasa sacra, ktoré prichádzali do priameho kontaktu so sviatostou. Celocirkevné predpisy presne určujúce materiál či formu cibórií v stredoveku však neexistovali. Štvrtý Lateránsky koncil (1215) nariad’oval len uchovávat' sviatost' zamknutú a chránenú pred svätokrádežou. Partikulárne cirkevné predpisy s lokálnou platnost’ou určujúce materiál sa však vydávali a v rôznych variáciách povol’ovali zlato, striebro, cín, pozlátenú med', slonovinu, limožské emailové práce, neskôr zliatiny medi. Už od 11. storočia boli cibória obvykle vyhotovované z pozlátenej medi, bronzu, prípadne striebra (Braun 1932, 291-298; Grove Encyklopedia 2012, 87; Kolba 2004, 17). Do tohto obrazu zapadá materiálové zloženie budmerického krucifixu, ako aj príklady vyššie spomínaných uhorských cibórií, ktoré boli vyhotovené väčšinou z pozlátenej medi.

V uvedenom kontexte možno budmerický krucifix identifikovat' ako potenciálne torzo cibória, ktoré je v danom chronologickom rámci vzácne aj v širšom stredoeurópskom kontexte.

\section{Proveniencia krucifixu}

Ďalšiu otázku vo vztahu k budmerickému krucifixu si môžeme položit’ v súvislosti s jeho provenienciou. Autorstvo zlatníckych prác v stredoveku je až na ojedinelé výnimky takmer nezistitel'né (Cónová 2002, 99; Kolba 1983, 300; 1987, 369). ${ }^{6}$ Istý progres v tejto problematike by ešte mohol priniest' archívny výskum kostolných inventárov.

Uvažovat' o autorstve, resp. proveniencii krucifixu tak možno len rámcovo. V staršom románskom období zlatnícka liturgická produkcia vznikala najmä pri kláštoroch a cirkevných centrách (kapituly, biskupstvá), prípadne v královských dielňach (Lovag 1999, 8, 9). V období, do ktorého spadá budmerický exemplár, začal rást' význam mestských remeselníkov. V 14. storočí sa spracovanie kovov presunulo do miest, najmä v regiónoch bohatých na rudy (Lovag 1999, 9), a v období po tatárskom vpáde tu isto mala vplyv nemecká kolonizácia, ktorá silno zal’udnila región medzi Bratislavou a Trnavou (Rábik 2010, 532; Slivka 1999, 27). Na západnom Slovensku sú doložené zlatnícke centrá v Bratislave a Trnave (Wetter 2011, obr. 22), pričom v staršom období bola významnejším centrom pravdepodobne Bratislava, ktorá sa stala hlavným sprostredkovatel'om obchodu Uhorska so západnou Európou (Lysá 2010, 117-120; Špiesz 1972, 28, 29, 307, 308; Toranová 1983, 11, 14, 15, 20, 21).

Budmerický krucifix predstavujúci torzo pôvodného predmetu nesie málo špecifických čŕt, ktoré by ul'ahčovali identifikovanie jeho proveniencie. S istotou môžeme konštatovat', že nevykazuje žiadnu afinitu s uhorskou produkciou románskych krucifixov (Lovag 1999). Čiastkové paralely vykazuje až na domácom materiáli zo 14. storočia. Istými indíciami je forma kríža s rozširujúcimi sa koncami, uplatňujúca sa v Taliansku a Švábsku, absentujúca tŕňová koruna, charakteristická taktiež pre tieto dva regióny. Pri účese a širokom čele korpusu sme identifikovali isté paralely na hornoporýnskych krížoch z 13. storočia a na talianskej plastike zo 14. storočia.

Skúmaný krucifix tak mohol vzniknút' v mestskej dielni, na ktorú mali vplyv uvedené regióny. Na západnom Slovensku pritom v danom čase mestskému remeslu dominoval nemecký

6 Aj v prípade relikviárového kríža zo Spišskej Novej Vsi, ktoré sa pripisovalo Nikolausovi Gallicovi (spomínaný na Spiši 1318-1342; Cónová 1999, 8), novšie bádanie už túto atribúciu spochybňuje (Wetter 2011, 24 - skratku NC číta ako Neocomium). 
živel prichádzajúci z južných nemeckých krajín (Lysá 2010, 117; Rábik 2010, 533, 534; Šedivý 2012, 438), ktorý so sebou prinášal aj nový gotický výtvarný prejav.

\section{Nálezový kontext}

Z dostupných informácií vieme, že krížik sa našiel na prelome 19. a 20. storočia v Budmericiach „na poli“. Pretože ide o torzo pravdepodobného liturgického predmetu, je možné ho asociovat's prevádzkou niektorého z existujúcich, prípadne zaniknutých kostolov v obci a jej okolí (obr. 5). Môžeme si tak bližšie všimnút' sakrálnu architektúru na území Budmeríc a v bezprostredne susediacich obciach (Častá, Štefanová, Borová, Ružindol, Jablonec, Vištuk, Dubová). Okrem pamiatkových výskumov sme o nej informovaní aj zo štúdia cirkevnej správy (Rábik 2010a, 48-85; Tibenský 2011, 130-137).

Písomné pramene ani dochovaná vrstva stredovekej architektúry priame doklady o existencii fár, prípadne kostolov v skúmanej oblasti v 13. storočí, s výnimkou Častej (1291) a Horného Fančala (1291, pozri nižšie), zatial' neponúkajú. Ich existenciu však nemožno vylúčit', ked’že osídlenie v tomto mikroregióne písomné zmienky potvrdzujú už od polovice 13. storočia (Rábik 2010a, 126-128; Súpis 1967, 142, 235, 263, 345, 346, 498; Súpis 1969, 66, 67, 253, 406, 407; Varsik 1984, 105-111, $115,118-120){ }^{7}$ Vo vzt’ahu k budmerickému krucifixu je možno dôležitejšia tá skutočnost', že kostoly v Budmericiach a okolitých obciach stáli, resp. stoja v ich centre, čo ich súvislost' s nálezom nájdeným na poli oslabuje.

Relatívne pravdepodobnejšie miesto

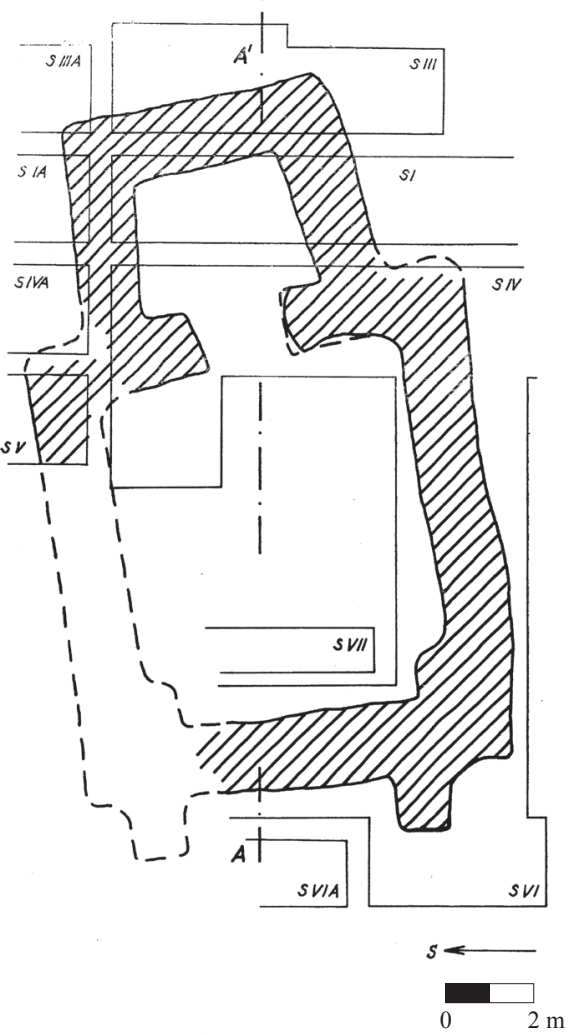

Obr. 4. Budmerice - Fančal. Pôdorys kostola. Podl’a Egyházy-Jurovská 1980, obr. 3.

Abb. 4. Budmerice - Fančal. Grundriss der Kirche. Nach Egyházy-Jurovská 1980, Abb. 3.

pôvodu budmerického krucifixu na skúmanom území by mohli predstavovat' zaniknuté kostoly. Podl’a J. Tibenského $(1998,221)$ ležala na území dnešného budmerického chotára (v trojuholníku Budmerice - Častá - Štefanová) zaniknutá obec Lattindorf. Farnost' má doloženú v roku 1335, novšie bádanie ju však lokalizuje presnejšie medzi Štefanovú a Častú, resp. až do blízkosti Častej (obr. 5; Rábik 2010a, 64, 65; Tibenský 2011, 135, 196, príloha č. 4; Varsik 1984, 109).

V susedstve Budmeríc, medzi Dol’anmi a Horným Fančalom (zaniknutá obec v katastri Budmeríc, pozri nižšie) sa nachádzala d’alšia zaniknutá dedina Bozna, resp. Bohna, ktorá má farnost’ doloženú v roku 1390. Dedina pravdepodobne ležala v dnešnom chotári Štefanovej (obr. 5), pričom podl'a J. Trochtu by mohlo íst' o polohu majera v obci (Rábik 2010a, 53, 54, pozn. 83).

Do úvahy ešte prichádzajú dva kostoly, ktoré sa nachádzali na rozsiahlom majetku označovanom ako terra Fonchal, čiastočne zasahujúcom aj do katastra Budmeríc. Na jeho území sa nachádzali dva kostoly - sv. Petra a sv. Ducha. Z privilégia Karola Róberta z roku 1323 vieme,

7 Vištuk 1244, Dubová 1287, Častá 1291, Horný Fančal 1291, Budmerice 1296. 
že Kostol sv. Ducha sa mal nachádzat' v časti označovanej ako Horný Fančal a Kostol sv. Petra v časti Dolný Fančal (Judák-Poláčik 2009, 43, 136, 252; Lukačka 2004, 40; Rábik 2010a, 54, 60; Tibenský 2011, 47; Žudel 1970, 21, 22).

Názor na lokalizáciu Dolného Fančala prešiel istým vývojom. J. Žudel (1970, 22-27, mapa 1; prevzal Habovštiak 1985, 264, 265) ho pôvodne situoval do súčasného katastra Budmeríc, juhovýchodne v blízkosti obce, čo by z Kostola sv. Petra robilo relevantnú možnost' pre lokalizáciu skúmaného krížika. Novšie bádanie už kostol situuje do Páca (od roku 1974 miestnou častou Cífera, Rábik 2010a, 54, 55, 68, 69, Sedlák 1996; 2004, 21, 22) a stotožňuje ho aj na základe architektonického výskumu s tu stojacim kostolom sv. Petra a Pavla (obr. 5; Bernadič et al. 1991, 102, 103, 131-133; Haviarová-Zvedelová 2011; 2012). Kostol sv. Petra v Dolnom Fančale, resp. Páci sa pre fyzickú ako aj správnu vzdialenost' viacerých chotárov javí už málo pravdepodobná.

Poslednou alternatívou zostáva dedina Horný Fančal, kde sa podl'a listín z roku 1291 a 1323 mal nachádzat’ Kostol sv. Ducha (Judák-Poláčik 2009, 43; Polla 1959, 520; Rábik 2010a, 34, 54, 60; Žudel 1970, 21, 23, 24, 28). Kostol sa podarilo lokalizovat' v extraviláne Budmeríc v časti, ktorá si zachovala chotárne pomenovanie Fančal, a archeologicky ho preskúmat' (obr. 5; Egyházy-Jurovská 1975; 1976; 1980; 1981; Gajdoš 1980). Bol tu odkrytý jednolod’ový románsky kostol so štvorcovou apsidou (obr. 4). Autorka výskumu kostol datovala do druhej polovice 13. storočia a radí ho do prechodného obdobia od románskeho ku gotickému slohu. Tento stavebný typ sa vo všeobecnosti spája s nemeckou kolonizáciou nasledujúcou po tatárskom vpáde. Podl’a aktuálneho poznania k vel'kému rozšíreniu tohto typu kostola dochádza až v 13. storočí, najmä v jeho druhej polovici (Pomfyová 2009, 752-759).

Z uvedených alternatív je do extravilánu Budmeríc lokalizovaný len Horný Fančal a rovnako len $\mathrm{v}$ jeho prípade vieme potvrdit' existenciu kostola podl'a písomných, ako aj archeologických prameňov v 13. storočí. Súvislost' krucifixu s konkrétnym kostolom však nie je možné bezpochyby doložit’ a ich potenciálny vzt'ah tak môže zostat' len v hypotetickej rovine.

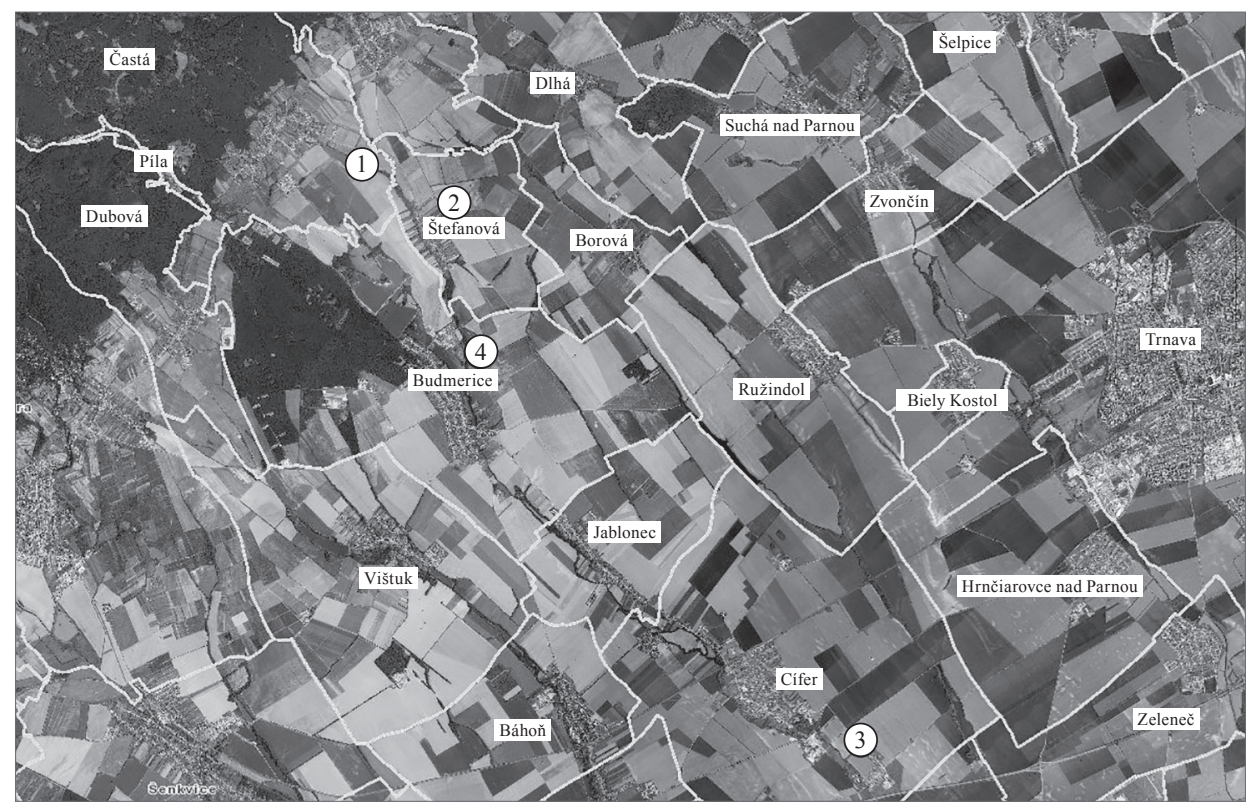

Obr. 5. Mapa Budmeríc a okolia s vyznačenými katastrami a polohou zaniknutých dedín/sakrálnych stavieb spomínaných v texte. Legenda: 1 - Lattindorf; 2 - Bozna/Bohna; 3 - Dolný Fančal; 4 - Horný Fančal.

Abb. 5. Karte von Budmeríce und Umgebung mit eingezeichneten Katastern und gekennzeichneter Lage der im Text erwähnten Dorfwüstungen/untergegangenen Sakralbauten. Legende: 1 - Lattindorf; 2 - Bozna/Bohna; 3 - Dolný Fančal; 4 - Horný Fančal. 


\section{Literatúra}

ALBU, I., 2009: Die Engelsprüche am Westportal der Marienkirche in Hermannstadt. In: Saşii şi concetăţenii lor ardeleni. Studia in Honorem Dr. Thomas Nägler (Ţiplic, I. M.-Gündish, K., edd.), 95-122. Alba-Iulia. BERNADIČ, L., et al., 1991: Cífer. Vlastivedná monografia. Cífer.

BIELZ, J., 1957: Die sächsische Goldschmiedekunst Siebenbürgens. Bukarest.

BLOCH, P., 1992: Romanische Bronzekruzifixe. Bronzegeräte des Mittelalters 5. Berlin.

BODOR, I., 1983: Két bronz corpus a 14. századi visegrádi öntőműhelyből, Művészettörténeti Értesítő 32, 165-167.

BRAUN, J., 1932: Das christliche Altargeret. In seinem sein und in seiner Entwicklung. München.

- 1940: Die Reliquiare des chrisltichen kultes und ihre Entwicklung. Freiburg im Breisgau.

CÓNOVÁ, I., 1999: Gotické zlatnícke liturgické pamiatky na Slovensku. Interný materiál Pamiatkového úradu SR. Bratislava.

- 2002: Gotické zlatnícke liturgické predmety na Slovensku - inventár, Galéria 2002 - Ročenka Slovenskej národnej galérie, 99-122.

CSÉFALVAY, P., 1984: Az esztergomi Főszékesegyházi Kincstár. Budapest.

- 1992: Az esztergomi Bazilika, Kincstár és Vármúzeum. Budapest.

DIVALD, K., 1907: Szepesvármegye müvészeti emlékei 3. Iparművészeti emlékek. Budapest.

ÉBER, L., 1907: Gíergl Kálmán gyüjteménye, Magyar Iparmüvészet 10, 57-95.

EGYHÁZY-JUROVSKÁ, B., 1975: Archeologický výskum v Budmericiach, Vlastivedný časopis XXIV/2, $89,90$.

- 1976: Zistovací archeologický výskum v Budmericiach, okres Bratislava-vidiek, roku 1971, ZbSNM LXX História 16, 55-90.

- 1980: Zaniknutý románsky kostol s cintorínom v Budmericiach okr. Bratislava-vidiek, ZbSNM LXXIV História 20, 39-61.

- 1981: Zaniknutá stredoveká dedina Fančal - Die mittelalterliche Ortswüstung Fančal, AH 6, 513-519.

FRITZ, J. M., 1982: Goldschmiedekunst der Gotik im Mitteleuropa. München.

GAJDOŠ, V. 1980: Geofyzikálne práce na lokalite Budmerice, ZbSNM LXXIV História 20, 61-65.

GETTY 1270: Marquette Bible, vol. 1, about 1270, Ms. Ludwig I 8 (83.MA.57), v1, The J. Paul Getty Museum, Los Angeles. Dostupné z: http://www.getty.edu/art/collection/objects/1344/unknown-maker-marquette-bible-vol-1-franco-flemish-about-1270/?dz=0.3823,1.1540,3.55.

GETTY 1300: Initial G: The Crucifixion, about 1300, Ms. Ludwig IX 3 (83.ML.99), fol. 102, The J. Paul Getty Museum, Los Angeles. Dostupné z: http://www.getty.edu/art/collection/objects/3405/unknown-maker-initial-g-the-crucifixion-french-about-1300/?dz=0.1664,0.2177,3.00.

GROVE ENCYKLOPEDIA 2012: The Grove Encyklopedia of Medieval Art and Architecture (Hourihane, C. P., ed.). Oxford.

HABOVŠTIAK, A., 1985: Stredoveká dedina na Slovensku. Bratislava.

HAVIAROVÁ, M.-ZVEDELOVÁ, K., 2011: Stavebno-historický vývoj Kostola sv. Petra a sv. Pavla v Cíferi-Páci s dôrazom na románske stavebné etapy, Pamiatky Trnavy a Trnavského kraja 14, 39-46.

- 2012: Kostol sv. Petra a sv. Pavla v Cíferi-Páci, Pamiatky a múzeá 2012, č. 1, 51-55.

JUDÁK, V.-POLÁČIK, Š., 2009: Katalóg patrocínií na Slovensku. Bratislava.

KOLBA, J. H., 1975: Zwei gotische Ziborien im Ungarischen Nationalmuseum, Acta Historiae Artium 21, 3-4. szám, 283-332.

- 1980: Vésett gótikus talpas keresztjeink, Folia archeologica 31, 239-263.

- 1983: Ötvösség. In: A művészet I. Lajos király korában 1342-1382 (Marosi, E. -Tóth, M.-Varga, L., edd.), 297-301. Budapest.

- 1983a: 165. Körtvélyesi cibórium. In: A művészet I. Lajos király korában 1342-1382 (Marosi, E.-Tóth, M.Varga, L., edd.), 310, 311. Budapest.

- 1987: Ötvösség. In: Magyarországi mủvészet 1300-1470 körül (Marosi, E., ed.), 369-373. Budapest.

- 2004: Liturgische Goldschmiedearbeiten im Ungarischen Nationalmuseum. 14.-17. Jahrhundert. Catalogi Musei Nationalis Hungarici. Series Mediaevalis et Moderna I. Budapest. 
KOUŘIL, P., 2014: Archaeological evidence of Christianity in relics of material culture of the 9th and 10th centuries in Moravia with focus on crosses. In: The Cyril and Methodius Mission and Europe - 1150 Years Since the Arrival of the Thessaloniki Brothers in Great Moravia (Kourril, P., et al.). Brno.

KOVÁCS, É., 1968: Limoges champlevé enamels in Hungary. Budapest.

LEXIKON DER KUNST 1971: Lexikon der Kunst. Architektur, bildende Kunst, angewandte Kunst, Industrieformgestaltung, Kunsttheorie (Olbrich, H., Hrsg.). Band 2. Leipzig.

LOVAG, Z., 1979: Mittelalterliche Bronzekunst in Ungarn. Budapest.

- 1994: V-18. Korpusz. In: Pannonia Regia. Művészet a Dunántúlon 1000-1541 (Mikó, Á.-Takács, I., edd.), 303. Budapest.

- 1999: Mittelalterliche Bronzgegenstände des Ungarischen Nationalmuseum. Catalogi Musei Nationalis Hungarici. Seria Archeologica 3. Budapest.

LUKAČKA, J., 2004: Majetky šl'achticov z Lefantoviec v širšom okolí Trnavy v stredoveku. In: Studia Historica Tyrnaviensia IV, 40-47. Trnava.

LYSÁ, Ž., 2010: Bratislava. In: Lexikon stredovekých miest na Slovensku (Štefánik, M.-Lukačka, J., a kol.), 105-139. Bratislava.

MAROSI, E., 1983: 183. Feszület-corpus. In: A művészet I. Lajos király korában 1342-1382 (Marosi, E.Tóth, M.-Varga, L., edd.), 325. Budapest.

- 1985: Die europäische Stellung der Kunst der Anjouzeit in Ungarn. Alba Regia, Annales Musei Stephani Regis XXII, 39-49.

MUDRA, A., 2017, ed.: V oplatce jsi všecek tajně. Eucharistie v náboženské a vizuální kultuře Českých zemí do roku 1620. Praha.

MÜLLER, B., 1994: Gotische Bronzekruzifixe. Dissertation. Freie Universität Berlin. Berlin.

ONASCH, K., 1981: Liturgie und Kunst der Ostkirche in Stichworten. Leipzig.

POLLA, B., 1959: Stredoveké obilné jamy v Budmericiach, Slovenský národopis VII/4, 517-559.

POMFYOVÁ, B., 2009: Stredoveká sakrálna architektúra v regióne Gemer a Malohont - Mittelalterliche Sakralarchitektur in der Region Gemer und Malohont (Kleinhont), AH 34, 745-762.

RÁBIK, V., 2010: Trnava. In: Lexikón stredovekých miest na Slovensku (Štefánik, M.-Lukačka, J., a kol.), 523-551. Bratislava.

- 2010a: Formovanie farskej siete na juhozápadnom Slovensku v stredoveku (Bratislavské prepošstvo). In: Vývoj cirkevnej správy na Slovensku (Rábik, V., a kol.), 29-131. Trnava - Kraków.

ROGANSKÝ, L., 2009: Signa Christiana. Artefakty krest’anského rázu z poslednej tretiny prvého tisícročia medzi Čechami a Potisím. Nitra.

ROTH, V., 1908: Geschichte des deutschen Kunstgewerbes in Siebenbürgen. Strassburg.

- 1922: Kunstdenkmaler aus den sachsischen Kirchen Siebenburgens. Hermannstadt.

RUTTKAY, A., 1979: Stredoveké umelecké remeslo. Bratislava.

RÚZSA, G., 1986: Ikonok az Ipolyi-gyűjteményben. In: Ipolyi Arnold emlékkönyv (Cséfalvay, P.-Ugrin Emese, E., edd.), 116-152. Budapest.

SEDLÁK, V., 1996: Budmerice v stredoveku. Budmerice.

- 2004: Sídlisko v kolobehu dejín, Historický zborník 14/1, 13-29.

SLIVKA, M., 1999: Umelecké remeslo na Slovensku v románskej dobe, Pamiatky a múzeá 48, č. 2, $27-32$.

STEHLÍKOVÁ, D., 2003: Encyklopedie českého zlatnictví, stř́íbrnictví a klenotnictví. Praha.

SUCKALE, R., 2003: Krucifix v Lendaku. In: Gotika. Dejiny slovenského výtvarného umenia (Buran, D., a kol.), 690-691. Bratislava.

SÚPIS 1967: Súpis pamiatok na Slovensku. 1. Bratislava.

SÚPIS 1969: Súpis pamiatok na Slovensku. 3. Bratislava.

SZMODIS-ESZLÁRY, É., 1977: Corpus en bronze des débuts du quattrocento florentin, A Szépmúvészeti Múzeum közleményei 48-49, 71-85.

ŠEDIVÝ, J., 2012: Od županovho podhradia ku král’ovskému mestu. Vývoj Prešporka/Bratislavy po 12. storočí. In: Dejiny Bratislavy 1 (Šedivý, J.-Štefanovičová, T., edd.), 431-439. Bratislava.

- 2018: Historické nápisy a ich nosiče. Corpus Inscriptionum Slovaciae I.3. Bratislava.

ŠOUREK, K., 1938: Práce v kovu a zlatnictví ve středověku. In: Umění na Slovensku (Šourek, K., ed.), 33-40. Praha. 
ŠPIESZ, A., 1972: Remeslo na Slovensku v období existencie cechov. Bratislava.

TARI, E., 2018: Kőbe faragott liturgia. A Kárpát-medence középkori kő keresztelömedencéi. Budapest.

TIBENSKÝ, M., 2011: Červenokamenské panstvo v stredoveku. Trnava - Kraków.

TOGNER, M.-PLEKANEC, V., 2012: Medieval wall paintings in Spiš. Bratislava.

TORANOVÁ, E., 1983: Zlatníctvo na Slovensku. Bratislava.

- 1991: Medikováčstvo. Bratislava.

UZSOKI, A., 1984: I. András király sírja Tihanyban és a sírlap ikonográfiai vonatkozásai, A Veszprém

Megyei Múzeumok Közleményei 17, 145-188.

VARSIK, B., 1984: Z osídlenia západného a stredného Slovenska v stredoveku. Bratislava.

VÍZI, M.-MIKLÓS, Z., 1999: Előzetes jelentés a középkori Ete mezőváros területén végzett kutatásokról,

A Wosinszky Mór Múzeum Évkönyve XXI, 207-269.

WETTER, E., 2003: 7.1 Kríž s relikviou v Spišskej Novej Vsi. In: Gotika. Dejiny slovenského výtvarného umenia (Buran, D., ed.), 805. Bratislava.

- 2011: Objekt, Überlieferung und Narrativ. Spätmittelalterliche Goldschmiedekunst im historischen Königreich Ungarn. Studia Jagellonica Lipsiensia 8. Ostfildern.

WICK, B., 1936: A kassai Szent Erzsébet dóm. Košice.

ŽUDEL, J., 1970: Príspevok k historickej geografii Trnavskej pahorkatiny do polovice 16. stor. Horný Fančal, Dolný Fančal, Budmerice, Geografický časopis XXII, č. 1, 19-38.

\section{Zusammenfassung}

\section{Ein frühgotisches Kruzifix aus Budmeríce (Bezirk Pezinok)}

Der auf einem Feld außerhalb des Bebauungsgebietes von Budmerice gemachte Zufallsfund eines kleinen Kupferkruzifixes stellt wahrscheinlich den Torso eines liturgischen Gegenstandes dar. Im Hinblick auf seine Maße und die selten vorkommende Form des Kreuzes könnte es Bestandteil eines Ziboriums gewesen sein. Parallelen zu ihm stellen Kreuze dar, mit denen aus Spišský Hrušov (datiert um 1360), aus der siebenbürgischen Gemeinde Cisnădioara (Michelsberg, zweites Viertel 14. Jahrhundert) und der Privatsammlung von G. Kálman (15. Jahrhundert) stammende poygonale Ziborien abgeschlossen wurden. Das Kreuz wurde aus Blech herausgeschnitten und der Korpus separat in einer einseitig offenen Form gegossen. Beide Teile wurden mit Nieten miteinander verbunden und auf beiden Seiten vergoldet. Kreuz und Korpus wurden aus Kupfer hergestellt. Zusammensetzung und Ausführung des Kruzifixes entsprechen der allgemein dokumentierten Praxis, aber auch den kirchlichen Vorschriften für die Herstellung eines solchen Kultobjektes. Der mit drei Nieten am Kreux befestigte Korpus wurde im frühgotischen Stil gefertigt und wird von uns in das zweite bis dritte Drittel des 13. Jahrhunderts datiert. Der Fund könnte mit der außerhalb des Bebauungsgebietes von Budmerice liegenden Dorfwüstung Horný Fančal und der dortigen verschwundenen Heilig-Geist-Kirche aus dem 13. Jahrhundert zusammenhängen. Dieser Zusammenhang kann jedoch nicht zweifelsfrei nachgewiesen werden, da sich der genaue Fundort nicht mehr lokalisieren lässt.

Mgr. Martin Hanuš, PhD., Slovenské národné múzeum-Archeologické múzeum, Žižkova 12, P. O. Box 13, 81006 Bratislava, Slovenská republika, martin.hanus@snm.sk

Toto dílo lze užít v souladu s licenčními podmínkami Creative Commons BY-NC-ND 4.0 International (https://creativecommons.org/licenses/by-nc-nd/4.0/legalcode). Uvedené se nevztahuje na díla či prvky (např. obrazovou či fotografickou dokumentaci), které jsou v díle užity na základě smluvní licence nebo výjimky či omezení př́islušných práv. 
